\title{
Adaptive Expertise: A study on the influence of self-determination and transformational leadership
}

\author{
MARIA TEREZA TOMÉ DE GODOY ${ }^{1}$ \\ Helenides MENDONÇA ${ }^{2}$
}

\author{
${ }^{1}$ Universidade Federal de GoIÁs (UFG) / Pró-ReItoria de GestÃo de PeSSOAS, GoIÂNIA - GO, BraZIL \\ 2 Pontifícia Universidade Católica de Golás (PUC Golás) / Departamento de Psicologia, GoiÂnia, GoiÂnia - GO, BraZIL
}

\begin{abstract}
This study aimed to analyze the role of transformational leadership in adaptive expertise and test the mediating role of self-determination in this relationship by satisfying the psychological needs of autonomy, belonging, competence and achievement. The survey was conducted with 383 Brazilian workers. The collected data were analyzed through confirmatory factorial analysis (CFA) and multiple regressions. The results of the analyses made it possible to highlight the positive relationship between transformational leadership, adaptive expertise, and self-determination. Quadruple mediation analysis was performed to evidence the effect of self-determination on the relationship between transformational leadership and adaptive expertise. The results confirm the effect of the transformational leader on competence and the mediating effect of self-determination in this relationship. This research advances in the job demands-resources (JD-R), confirming the importance of the worker's resources and personal resources.
\end{abstract}

Keywords: Adaptive Expertise. Self-Determination Theory. Transformational Leadership. JD-R.

\section{Competência Adaptativa: um estudo sobre a influência da autodeterminação e da liderança transformacional}

\section{Resumo}

Este estudo teve como objetivo analisar o papel da liderança transformacional na competência adaptativa e, ao mesmo tempo, testar o papel mediador da autodeterminação nessa relação por meio da satisfação das necessidades psicológicas de autonomia, de pertencimento, de competência e de realização. A pesquisa foi realizada com 383 trabalhadores brasileiros. Os dados coletados foram analisados por meio de análise fatorial confirmatória (AFC) e regressões múltiplas. Os resultados das análises possibilitaram evidenciar a relação positiva entre liderança transformacional, competência adaptativa e autodeterminação. Foi realizada análise de mediação quádrupla para evidenciar o efeito da autodeterminação na relação entre liderança transformacional e competência adaptativa. Os resultados confirmam o efeito do líder transformacional na competência e o efeito mediador da autodeterminação nesta relação. A pesquisa avança no modelo de recursos e demandas do trabalho (RDT) confirmando a importância do recurso do trabalho e dos recursos pessoais do trabalhador.

Palavras-chave: Competência adaptativa. Teoria da autodeterminação. Liderança transformacional. RDT.

\section{Competencia Adaptativa: un estudio sobre la influencia de la autodeterminación y del liderazgo transformador}

\section{Resumen}

Este estudio tuvo como objetivo analizar el papel del liderazgo transformacional en la competencia adaptativa y, al mismo tiempo, probar el papel mediador de la autodeterminación en esa relación por medio de la satisfacción de las necesidades psicológicas de autonomía, de pertenencia, de competencia y de realización. La encuesta se llevó a cabo con 383 trabajadores brasileños. Los datos recolectados se analizaron por medio de análisis factorial confirmatorio (AFC) y regresiones múltiples. Los resultados de los análisis posibilitaron evidenciar la relación positiva entre liderazgo transformacional, competencia adaptativa y autodeterminación. Se realizó un análisis de mediación cuádruple para evidenciar el efecto de la autodeterminación en la relación entre liderazgo transformacional y competencia adaptativa. Los resultados confirman el efecto del líder transformacional en la competencia y el efecto mediador de la autodeterminación en esta relación. La investigación avanza en el modelo de recursos y demandas del trabajo (RDT) al confirmar la importancia del recurso del trabajo y de los recursos personales del trabajador.

Palabras clave: Competencia adaptativa. Teoría de la autodeterminación. Liderazgo transformacional. RDT. 


\section{INTRODUCTION}

The transformations of the job market have intensified in recent years, especially due to the introduction of technology making the organizational environment more volatile, uncertain, complex and ambiguous. If on one hand, this scenario requires workers to be capable of adapting quickly to change, on the other, leaders have come to play a fundamental role in changes in behavior, in the capacity to adapt, and the motivation of workers in the face of constant challenges in the organizational environment.

In this scenario, it is essential to adjust quickly and provide quick responses with greater flexibility and fluency in dealing with initial demands and unknown work situations (MUSTONEN and HAKKARAINEN, 2015; GEGENFURTNER, LEHTINEN, JARODZKA et al., 2017). Nonetheless, it is known that the behavior of workers can be preceded and influenced by context, such as the impact of transformational leadership (OLIVEIRA MACIEL and NASCIMENTO, 2013; BREEVAART, DEMEROUTI, DERKS et al., 2016)studies on leadership use an atomistic approach which ignores the effects of different configurations (gestalts and intrinsic motivation, such as the influence of self-determination (DECI and RYAN, 2014; TORRES and SIDOROVA, 2015; HOWARD, GAGNÉ, MORIN et al., 2016).

In this study, we investigate the impact of the context of personal resources on the adaptive behavior of workers. To accomplish this, two basic theories sustain established relationships, namely the Job Demand-Resources (JDR) Model, advanced by Bakker and Demerouti (2001); and the Self-Determination Theory (SDT), proposed by Deci and Ryan (2000).

The JDR model explains the relationship between job demands and resources. Job demands are aspects of work which inflict certain physical, psychological and emotional costs on the worker. Job resources are considered to be physical, psychological, social and organizational aspects of work which support the behavior and well-being of the worker. The availability of resources within the job context can reduce the impact caused by demands and costs of a physiological and psychological nature (SCHAUFELI, DIJKSTRA and VAZQUEZ, 2013).

Padsokoff, Le Pine and Le Pine (2007) argue that demands can be classified as obstacles and challenges. Challenges are related to a job's complexity, the processing of information and the resolution of problems. These demands differ from job resources when we analyze the established relationship with engagement and burnout. While job resources have dichotomic relationships, challenges can have a positive relationship with engagement as well as burnout. When workers respond successfully to such a challenge, they feel more confident and self-realized, as they recognize that the efforts they have made can generate future gains (CRAWFORD, SCHLAGER, TOYAMA et al., 2005; CRAWFORD, LEPINE and ERICH, 2010; ALBRECHT, 2015).

Great challenges, associated with great work and personal resources, can generate a feeling of power (DEBUSSCHER, HOFMANS and DE FRUYT, 2017). In 2014, Bakker came to consider, in his empirical studies, the influence of personal resources on workers in the relationship between demands and job resources. Thus, workers with heightened personal resources are characterized by their tenacity and persistence in the face of challenges, with optimism and motivation driving them toward better results.

Considered to be an important personal resource when facing work demands, self-determination alters the way in which a worker views the organizational environment. Self-determination is considered by theorists to be a type of intrinsic motivation which is considered to be the internal locus of control within the intentional domain which alters the individual's own well-being (RYAN and DECI, 2000; HOWARD, GAGNÉ, MORIN et al., 2016).

To self-determination theory, people are capable of modifying their perceptions of a context through self-determination by satisfying basic psychological needs (RYAN and DECl, 2000). Someone who has self-determination has a domain that he or she has influence over. These theorists understand this domain as satisfying basic psychological needs such as competence, belongingness and autonomy (ALBRECHT, 2015; DECI and RYAN, 2014) and these needs have interrelated and stimulating mutual effects (BIDEE, VANTILBORGH, PEPERMANS et al., 2017).

Despite valuable theoretical and empirical contributions about the relationships between demand, context and personal variables, it is fundamental to make a deeper study that relates adaptive expertise to the influence of contextual factors, such as transformational leadership, and personal resources, such as autonomy. Thus, with studies of adaptive expertise, 
transformational leadership and restless autonomy, we can understand how these demand, context and personal variables can interact and the significance that these variables play in worker behavior. To better structure this article, the justification of our selection of variables, the relationships between them, and the hypotheses examined in this study will be argued in the theoretical reference section.

In this study, we will consider the JDR model and the SRT which are based on researching the relationship between personal and contextual variables. The objective of this empirical study is to investigate the impact of transformational leadership on autonomy and adaptive expertise. More specifically, the proposal is to evaluate the role that a worker's self-determination has in the relationship between a transformational leader and the worker's adaptive expertise.

To accomplish this, we will address in greater detail the concepts of each variable in this study, justifying the selection of our variables and the relationships between them. This relationship is based on similar variables which sustain the elaboration of the hypothetical research model.

\section{THEORETICAL REFERENCES}

\section{Adaptive expertise}

Adaptive expertise was originally conceived of by Hatano and Inagaki (1984) in their studies and they came to differentiate adaptive expertise from routine competence, although, as difinition, iti is an specific kind of competence. Thus, adaptive expertise is defined as the capacity that workers have to develop new knowledge and abilities based on those that they already have, obtaining efficient results with high performance in new and unknown situations (ANTHONY, HUNTER and HUNTER, 2015; CARBONELL, KÖNINGS, SEGERS et al., 2016; GODOY and MENDONÇA, 2020).

To better understand the interactions that exist in adaptive expertise, we need to address the interaction between the dimensions which are the specific domain, meta-cognitive, innovation, and autonomy. The specific domain refers to a domain of knowledge and abilities and the performance of a specific activity; meta-cognitive is the capacity to learn based on operationalized competencies; innovation is the capacity to create and develop solutions; autonomy is the capacity for self-regulation and confidence in one's capacity to apply one's knowledge and abilities (AXELSSON and JANSSON, 2018; CARBONELL, KÖNINGS, SEGERS et al., 2016; CARBONELL, STALMEIJER, KÖNINGS, 2014; DE CORTE, 2014).

Adaptive expertise refers to one's capacity of adaptability in terms of new job demands. In terms of this point, it is important to point out that the concept is removed from the idea of static and/or conformist behavior; on the contrary, adaptive expertise refers to constant self-evolving behavior and changes in behavior and the perception of the scenario. Adaptability is a behavioral competency which, like other behaviors, has been related to good performance in the business world (CARBONELL, KÖNINGS, SEGERS et al., 2016; CARBONELL, STALMEIJER, KÖNINGS, 2014; GODOY and MENDONÇA, 2020).

Thus, adaptive expertise presents itself as an integrative and complete concept of behavior that responds to the desires of organizations in the new millennium. Adaptability absorbs, adapts and adjusts behavior to the demands of work; and innovation comes from a belief in oneself, through auto-efficacy and creativity (CARBONELL, KÖNINGS, SEGERS et al., 2016; CARBONELL, STALMEIJER, KÖNINGS, 2014; GODOY and MENDONÇA, 2020).

\section{Transformational leadership}

Recent studies have frequently approached leadership in three ways: transformational, in which the focus is on the development of worker strengths and virtues; transactional, in which there is an exchange relationship between performance and recognition, and laissez-faire, in which there is no intervention of the leader in the behavior of the workers. The concept of transformational leadership was proposed by Burns in 1978 based on the political-social context of the successful behavior of great statesmen (CALAÇA and VIZEU, 2015). Later Bass (1999) suggested the understanding of transformational leadership based on idealized influence, inspiring motivation, intellectual stimulation and individualized consideration dimensions (HARDY, ARTHUR, 
JONES et al., 2010). These authors believed that the behavior of the dimensions of transformational leadership is strongly correlated, and therefore it forms a higher order construct (BASS, 1999; FERNET, TRÉPANIER, AUSTIN et al., 2015).

In the idealized influence dimension, the leader is a model to be followed in his or her actions who acquires the respect and confidence of the entire team. In inspiring motivation, the leader encourages and stimulates, in a strategic manner, the achievement of individual goals, and at the same time shares clear communication of the organization's strategic guidelines and objectives. In the intellectual stimulation dimension, the leader is capable of stimulating, in a strategic manner, the intellectual development of his team and stimulating the development of creativity, innovation and independent thinking. In this way, the leader fully supports the continual development of proteges, promoting changes in their attitudes and their personal and professional performance. Considering each individual one at a time, the leader is capable of analyzing their behavior and adapts this approach to assisting each of them in obtaining their individual goals. In this dimension, the leader's behavior enhances the worker's feeling of belongingness and this comes to be create a feeling of unity and oneness within the work context (BASS, 1999; JUDGE and PICCOLO, 2004; FERNET, TRÉPANIER, AUSTIN et al., 2015).

\section{Self-determination theory}

The self-determination theory elaborated by Ryan and Deci (2000) addresses human motivation based on the importance of the evolution of internal resources for the individual's personality and self-regulating behavior. Self-determination is a combination of behaviors and abilities related to the capacity of the individual to be the agent of his or her well-being in an intentional process. Self-determination behavior is characterized by being autonomous and self-regulated in a process of psychological empowerment which results in self-achievement (RYAN and DECI, 2000; APPEL, WENDT and ARGIMON, 2010).

To the SDT, motivation is influenced by satisfying basic psychological needs (RYAN and DECI, 2000). The psychological need for autonomy is associated with the worker's self-regulation, which thus determines the willingness to apply oneself to tasks and take on roles within the work environment (HOWARD, GAGNÉ, MORIN et al., 2016; GAGNÉ and DECI, 2005; DECI and RYAN, 2014). The psychological need for belongingness is seeking good relationships with others, whether it's with one's family or within the work environment, the individual needs to feel part of a group to feel valued (DECI and RYAN, 2014), connected with, accepted by, and understood by his or her group (ALBRECHT, 2015).

The psychological need for competence is related to the worker's desire to feel efficient, capable of solving challenges, of completing work that is of a satisfactory standard, and feeling confident about his or her performance at work. The SDT understands that the individual who is satisfied in terms of the psychological need for competence has more confidence in internal resources to perform tasks (DECl and RYAN, 2014). The satisfaction of the psychological need for competence is related to a great adaptability to context, and the constant search for learning and cognitive development (RYAN and DECI, 2014). On the other hand, people who are not satisfied with their competence in the face of demands at work feel less self-determination (TORRES and SIDOROVA, 2015).

Based on the studies of Eisenberger, Jones, Stinglhamber et al. (2005), Albrecht (2015) addresses the psychological need of achievement to better understand self-determination. Achievement is based on self-esteem, professional success through full capabilities in competencies, and a life of significance with personal meaning.

\section{Transformational leadership and adaptive expertise}

The transformational leader positively affects organizational commitment (MOSCON, 2015); has a positive impact on the productivity, dedication and well-being of those who work under him or her (OLIVEIRA MACIEL and NASCIMENTO, 2013); alters worker performance in the face of the organization's demands (SOANE, BOOTH, ALFES et al., 2018) and inspires and intellectually stimulates workers (BREEVAART, DEMEROUTI, DERKS et al., 2016; HARDY, ARTHUR, JONES et al., 2010).

The leader, considered as a work resource, assumes the fundamental role of the representative of the organization and also influences the behavior of the workers. The leader's transformational abilities provide a distinctive impact on work resources. Thus, it is believed, based on empirical studies, that the transformational leader can stimulate innovation and better adaptation 
in facing new situations. On the other hand, it is possible to understand that adaptive expertise depends on the organizational context and confidence established by the leader in a manner which is really appropriate for the workers. This leads to the understanding that a transformational leader positively influences the adaptive expertise of workers.

- Hypothesis 1: Transformational leadership is positively associated with adaptive expertise.

\section{Transformation leadership and self-determination}

Leaders with a transformational profile influence workers, helping them reach their potential in terms of self-efficacy and self-leadership (TIMS, BAKKER and XANTHOPOULOU, 2011; BREEVAART, DEMEROUTI, DERKS et al., 2016). Transformational leadership is related to a feeling of empowerment in workers and the satisfying of their psychological needs for competence (DEBUSSCHER, HOFMANS and DE FRUYT, 2017), driving workers to believe in their abilities (SOANE, BOOTH, ALFES et al., 2018). Transformational leadership generates greater confidence in the organization's workers and increases their identification with their work (OMAR, SALESSI and URTEAGA, 2016; RATIU, DAVID and BABAN, 2017). People satisfied in terms of their need for achievement are actively looking for challenges in a way in which they can fully utilize their abilities related to success (ALBRECHT, 2015).

What these studies demonstrate is that a transformational leader can positively influence the ability of workers to satisfy their psychological needs, making them more aware of their own autonomy, belongingness and achievement in relation to the work that they perform (Hypotheses $2 a, 2 b, 2 c$ and $2 d$ ). Thus, through interrelating these dimensions a transformational leader can provide workers with greater chances of achieving self-determination (Hypothesis 3 ).

- Hypothesis 2a: Transformational leadership is positively related to satisfying the psychological need for autonomy;

- Hypothesis $2 b$ : Transformational leadership is positively related to satisfying the psychological need for belongingness;

- Hypothesis 2c: Transformation leadership is positively related to satisfying the psychological need for competence;

- Hypothesis 2d: Transformational leadership is positively related to satisfying the psychological need for achievement;

- Hypothesis 3: There is a positive association between satisfying the psychological needs for autonomy, belongingness, competence and achievement.

\section{Adaptive expertise and self-determination}

Considering a worker's personal resources, self-determination can be crucial in scenarios that are highly demanding, diminishing their impact on the worker and improving organizational results (ALBRECHT, 2015; BIDEE, VANTILBORGH, PEPERMANS et al., 2017; GODOY and MENDONÇA, 2020; HOWARD, GAGNÉ, MORIN et al., 2016). Individuals with self-determination are more likely to develop in a challenging environment, will have more confidence in themselves (ALBRECHT, 2015; DECI and RYAN, 2014), and will tend to promote more positive results for the organization (HOWARD, GAGNÉ, MORIN et al., 2016). As a result, people with self-determination are more involved in the processes of innovation and have greater confidence in using new systems and technologies (REZVANI, KHOSRAVI, and DONG, 2017).

To scholars, workers with self-determination face challenges with positive behavior, and view organizational demands and their own context as opportunities for professional achievement. Thus, in the face of demands for adaptability, people with self-determination are apt to act with more confidence in their competence, belongingness to the team, and greater autonomy in their decisions (ALBRECHT, 2015; BIDEE, VANTILBORGH, PEPERMANS et al., 2017; GODOY and MENDONÇA, 2020; HOWARD, GAGNÉ, MORIN et al., 2016).

- Hypothesis 4a: Satisfying the psychological need for autonomy is positively associated with adaptive expertise;

- Hypothesis $4 b$ : Satisfying the psychological need for belongingness is positively associated with adaptive expertise;

- Hypothesis 4c: Satisfying the psychological need for competence is positively associated with adaptive expertise;

- Hypothesis $4 d$ : Satisfying the psychological need for achievement is positively associated with adaptive expertise. 


\section{The mediating role of self-determination}

As we have already analyzed, workers who have self-determination are capable of evaluating demands within the work context based on the command of their psychological and cognitive capacities. They find within themselves the causal relationship between their own well-being and intentional behavior of empowerment (CHINIARA and BENTEIN, 2016; RYAN and DECl, 2000; DECl and RYAN, 2014). Studies also show that self-determination alters the relationship between work demands and achieving results (HOWARD, GAGNÉ, MORIN et al., 2016), and in particular, it modifies the relationship between transformational leadership and the functional ideal of work (FERNET, TRÉPANIER, AUSTIN et al., 2015).

Based on this approach, it is possible to understand that there is evidence that workers with self-determination can deal better with organizational contexts and demands; as a result, leadership may not have that strong an effect on worker behavior and the willingness to innovate in new situations. It may be inferred, therefore, that satisfying psychological needs assumes a mediating role in the relationship between transformational leadership and adaptive expertise (Hypothesis 5).

- Hypothesis 5: The relationship between transformational leadership and adaptive expertise is mediated by the self-determination of workers.

In accordance with the hypothetical model created based on the theoretical references, this study analyzes the relationship between transformational leadership as a work resource, and adaptive expertise as a personal resource, at the same time in which we intend to identify the mediating power of self-determination in this relationship (satisfying the basic psychological needs of autonomy, belongingness, competence and achievement).

In addition, we intend to analyze to what extent transformational leadership and self-determination are associated with adaptive expertise. According to SDT, self-determination will be analyzed by the satisfaction of the psychological needs of autonomy, belongingness, competence and achievement. For our analyses, we will consider the psychological needs of individuals and their interrelationships.

To begin with, based on the theoretical references used to approach the proposed hypotheses, it has been possible to elaborate a hypothetical research model which is based on the presented methodological procedures. Figure 1 presents the relationship between the research variables and the analyzed hypotheses.

Figure 1

\section{Hypothetical Research Model}

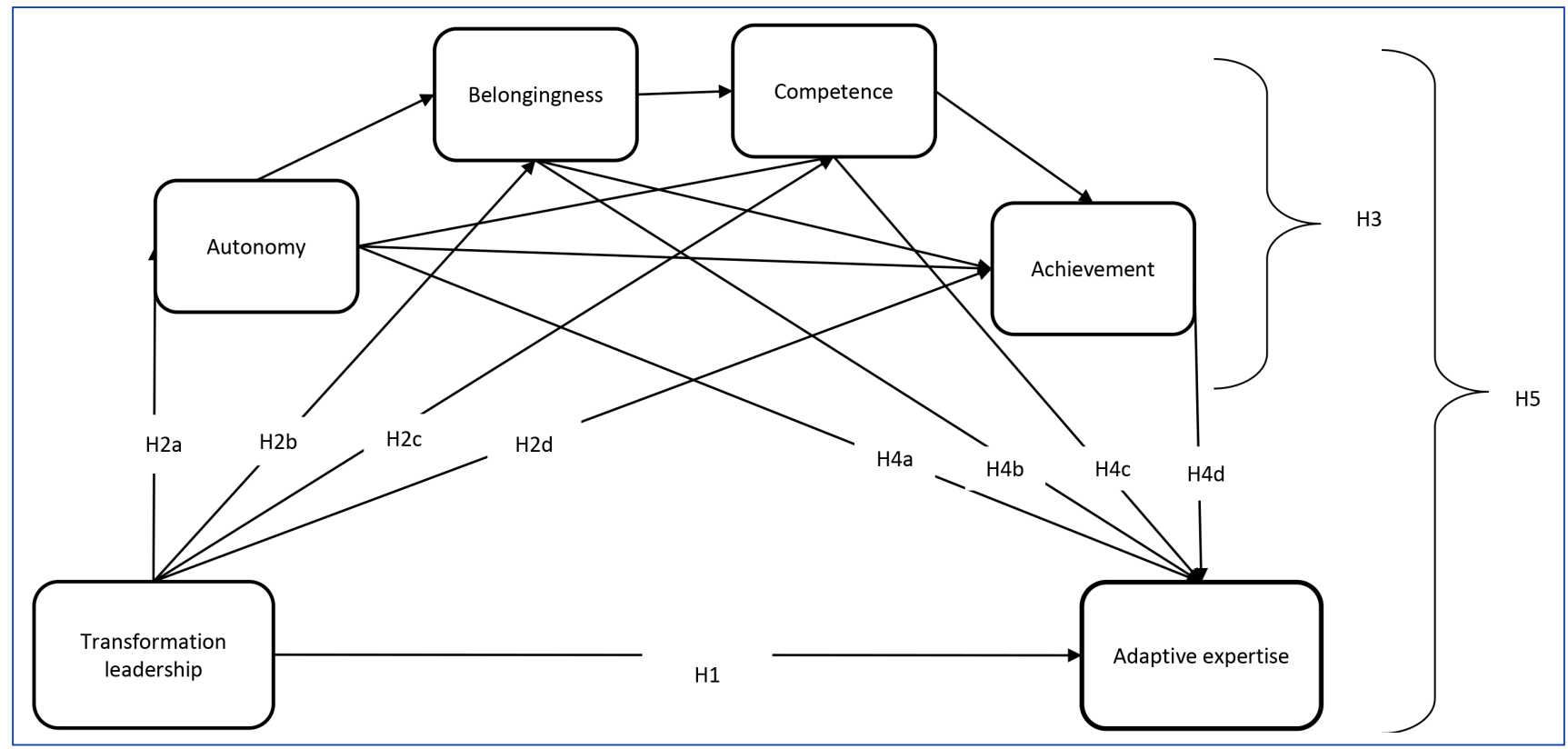

Source: Elaborated by the authors. 


\section{METHODOLOGICAL PROCEDURES}

\section{Procedures and participants}

To realize this study, we have followed every ethical procedure. The study was approved with the Ethics Committee of the Pontifical Catholic University of Goiás before beginning our data collection ${ }^{1}$.

The data collection was realized during the months of January and February 2017. Our criteria for those participating in the study were Brazilian workers over the age of 18 who are engaged in some form of work activity. The selection criteria for being invited to participate in the study began with convenience followed by the snowball approach. Once invited, the participant was encouraged to spread word of the study to friends, colleagues and family members who work.

In this manner, we sent the participant a link to access the study. This link led the participant to an online form after reading and signing the terms of free and informed consent (TCLE, according to Resolution no 510/2016 of the National Board of Health), and they were informed that they could cease participating in the study at any time.

Since the study was realized through an electronic form, there were no invalid forms or data missing in the scales; only the socio-economic data was open. Thus, of the 391 forms received, 8 forms were excluded because participants did not provide all the required socio-economic information. In all there were 383 participants considered in the study.

Most of the participants were from the State of Goiás (69.2\%), were of the female gender (57.4\%), were married (61.1\%), went to technical schools $(35.8 \%)$, worked in administration (38.1\%), in the public sector $(60.8 \%)$, and did not occupy leadership positions at the time of the data collection (57.2\%).

\section{MEASURES}

\section{Adaptive Expertise Inventory (ACI)}

Adaptive expertise was measured by the $\mathrm{ACl}$, which was validated with Brazilian workers by Godoy and Mendonça (2020) and features four dimensions and fourteen items, through self-evaluation using a five-point Likert scale ranging from totally disagree (1) to totally agree (5). For this study, we used the higher order dimension which includes all of the ACl items. Good fit indices were achieved in this study $\left(\chi^{2} / \mathrm{gl}=2.94 ; \mathrm{GFI}=0.93 ; \mathrm{CFI}=0.94 ; \mathrm{RMSEA}=0.07\right)$, and Cronbach's Alpha for the specific domain dimension was 0.79; meta-cognitive, 0.79; innovation, 0.70; and for adaptive expertise 0.90. Table 1 presents the factor loads for the $\mathrm{ACl}$ items.

Table 1

Factor Loads of the $\mathrm{ACl}$

\begin{tabular}{l|c}
\hline \multicolumn{1}{c|}{ Items } & $\begin{array}{c}\text { Factor } \\
\text { loads }\end{array}$ \\
\hline Specific domain & 0.68 \\
1. I am capable of developing and aggregating new knowledge with the knowledge that I \\
already possess. & 0.64 \\
2. I am concerned with the development of my competencies in order to realize my tasks. & 0.68 \\
3. I acquire a better understanding of my knowledge when I perform my tasks. & 0.70 \\
4. My knowledge of my tasks is constantly improving. & 0.59 \\
5. I need to be continually learning to be competent in my activities. & 0.70 \\
\hline Meta-cognitive & 0.74 \\
6. I demonstrate that I am willing to continue learning about how to perform my activities. & 0.68 \\
7. I apply my knowledge to new and unknown situations related to my activities. & 0.70 \\
8. I focus on new challenges. & \\
9. I work on new projects using the knowledge that I have learned from work in the past. &
\end{tabular}

${ }^{1}$ Certificate of the presentation of ethical appreciation (CAAE) $\mathrm{n}$ 0 62214416.0.0000.0037, report $\mathrm{n}$ ㅇ. 1.873.407. 


\begin{tabular}{l|c}
\hline \multicolumn{1}{c|}{ Items } & $\begin{array}{c}\text { Factor } \\
\text { loads }\end{array}$ \\
\hline Innovation & 0.71 \\
10. I am capable of maintaining my performance at a high level even when I am in new and & \\
unknown situations. & 0.80 \\
11. I am capable of applying my knowledge in a flexible manner for different activities at work. & 0.52 \\
12. I frequently question my command of my competencies. & 0.85 \\
\hline Autonomy & 0.88 \\
13. I have confidence in my ability to perform my activities. & \\
14. I believe in myself and in my capacity to produce effective results.
\end{tabular}

Source: Elaborated by the authors.

\section{Self-Determination Inventory (SDI)}

Self-determination was measured through SDI with the four dimensions and twelve items developed by Albrecht (2015) and validated for Brazilian workers by Godoy and Mendonça (2020). The SDI dimensions are psychological needs for autonomy, belongingness, competence and achievement (Table 2 presents the factor loads for the SDI items). The SDI was evaluated through self-reporting on a five-point Likert scale ranging from totally dissatisfied (1) to totally satisfied (5). In this study, the SDI had good fit indices in the proposed structure $\left(\chi^{2} / \mathrm{gI}=2.66 ; \mathrm{GFI}=0.93 ; \mathrm{CFI}=0.98 ; \mathrm{RMSEA}=0.06\right)$. Cronbach's Alpha in the psychological need dimension of autonomy was 0.86 ; belongingness, 0.87 ; competence, 0.92 ; achievement, 0.87 ; and self-determination, 0.93 .

Table 2

Factor Loads for SDI

\begin{tabular}{l|c}
\hline \multicolumn{1}{c|}{ Items } & $\begin{array}{c}\text { Factor } \\
\text { loads }\end{array}$ \\
\hline Achievement & 0.71 \\
1. You need to achieving something important through your work. & 0.84 \\
2. You need for a sense of accomplishment form what you do at work. & 0.87 \\
3. You need to make a positive contribution through your work. & \\
Belongingness & 0.81 \\
4. You need a sense of connection with the people you work with. & 0.92 \\
5. You need for genuine relationships with people at work. & 0.78 \\
6. You need to have friendship at work. & 0.61 \\
Autonomy & 0.94 \\
7. You need a sense of control over how you do your job. & 0.94 \\
8. You need autonomy in deciding how to do your work. & \\
9. You need freedom and independence in how you do your work. & 0.91 \\
Competence & 0.87 \\
10. You need for feeling competent at work. & 0.85 \\
11. You need for feeling capable of completing your work in a satisfactory standards. \\
12. You need for feeling confident about how you execute your work.
\end{tabular}

Source: Elaborated by the authors. 


\section{Transformational Leadership Inventory (TLI)}

Transformational leadership was measured through a version adapted by Moscon (2015) of the inventory developed by Bass and Avolio to evaluate leaders through from the perspective of people who work for them (AVOLIO, BASS and JUNG, 1999). The TLI has four dimensions and twelve items of transformational leadership, evaluated on a five-point Likert scale which ranges from totally disagree (1) to totally agree (5). Table 3 presents the factor loads of the TLI items. The TLI is designed to measure the perception of leaders through the eyes of those who work for them. The confirmatory analysis of the measure presented good fit indices $\left(\chi^{2} / \mathrm{gl}=2.73 ; \mathrm{GFI}=0.94 ; \mathrm{CFI}=0.72 ; \mathrm{RMSEA}=0.07\right)$ and a Cronbach's Alpha of 0.96 .

Table 3

Factor Loads for TLI

\begin{tabular}{l|c}
\hline \multicolumn{1}{c|}{ Items } & $\begin{array}{c}\text { Factor } \\
\text { loads }\end{array}$ \\
\hline Charisma or idealized influence & 0.88 \\
1. My immediate superior makes me feel comfortable by his or her side. & 0.55 \\
2. My immediate superior expresses in few words what I can and should do. & 0.82 \\
3. My immediate superior makes me think of old problems in a new way. & \\
Inspirational Motivation & 0.85 \\
4. My immediate superior helps me in my professional development. & 0.91 \\
5. I have complete trust in my immediate superior. & 0.89 \\
6. My immediate superior projects an encouraging image of what I can do. & 0.90 \\
Intellectual Stimulation & \\
7. My immediate superior provides me with new ways of looking at problematic \\
things. \\
$\begin{array}{l}\text { 8. My immediate superior lets me know what he or she thinks of what I am doing. } \\
\text { 9. I feel proud to work with my immediate superior. }\end{array}$ \\
Individualized Consideration & 0.79 \\
10. My immediate superior helps me find meaning in my work. & 0.94 \\
11. My immediate superior makes me rethink ideas that I never questioned before. \\
12. My immediate superior gives personal attention to employees that appear \\
rejected.
\end{tabular}

Source: Elaborated by the authors.

\section{Socio-demographic survey}

Age was declared in number of years. Gender is represented as 1 for female and 2 for male. Time at work: 1 for less than a year; 2 for 1 to 5 years; 3 for 6 to 10 years; 4 for 11 to 20 years; and 5 for more than 20 years of work.

\section{RESULTS}

\section{Measurement Model}

The statistical analyses for the data collected from Brazilian workers were realized using the Statistical Package for the Social Sciences (SPSS) software. In terms of the data collection, it was performed through self-reporting and a transversal cut, and we analyzed the common variance between the constructs, as suggested by Podsakoff, LePine and LePine (2003). We tested the model with the six proposed variables of the initial model and an alternative model with three variables.

For the global analysis of the model we considered the following indicators: $-\chi^{2} / g \mid-$ chi-squared in relation to the degree of freedom, GFI - goodness of fit index, CFI - comparative fit index and RMSEA - root mean square error of approximation (BROWNE and CUDECK, 1993). The model is considered adequate when $\chi^{2} / g \mathrm{~g} \leq 3 ; \mathrm{GFI} \geq 0,90 ; \mathrm{CFI} \geq 0,90 ; \mathrm{RMSEA} \leq 0,10$ (KLINE, 2014; BROWNE and CUDECK, 1993). 
For the analysis in this study, transformational leadership and adaptative competence were considered in the higher order dimension and self-determination in the dimensions of the psychological needs for autonomy, belongingness, competence and achievement. The hypothetical model with six factors (adaptive expertise, psychological need for autonomy, belongingness, competence, achievement and transformational leadership) was compared with the alternative model with three factors (adaptive expertise, self-determination and transformational leadership). The six factor model presented a better fit with the data $\left(\chi_{643}^{2}=1251.66 ; \chi^{2} / \mathrm{gl}=1.95 ; \mathrm{GFI}=0.92 ; \mathrm{CFI}=0.94 ; \mathrm{RMSEA}=0.05\right)$ than the three factor model $\left(\chi_{665}^{2}=2463.45 ; \chi^{2} / \mathrm{gl}\right.$ $=3.70 ; \mathrm{GFI}=0.74 ; \mathrm{CFI}=0.83 ; \mathrm{RMSEA}=0.08$ ). The analysis showed that the constructs are different and that the bias of the method does not represent a threat to the results (PODSAKOFF, MACKENZIE and LEE, 2003). It was not necessary to remove items for the analyses.

\section{Descriptive statistics}

Table 4 presents the descriptive statistics of average, standard deviation and Pearson's correlation for the control variables of age, gender, and time at work; and the latent variables transformational leadership; psychological need for autonomy, belongingness, competence, and achievement; general self-determination and adaptive expertise. All of the latent variables are positively associated and are significant $(p \leq 0.01)$.

Among the control variables - age, gender and time at work - and the latent variables, the results show that workers who are older and have been at work longer tend to evaluate their leaders as less transformational. A similar result occurs in the analyses in relation to satisfying the psychological need of belongingness. The older workers with more time at work tend to feel less belongingness than the younger workers.

Table 4

Descriptive Statistics, Average, Standard Deviation and Pearson's Correlation

\begin{tabular}{l|cccccccccc}
\hline \multicolumn{1}{l}{} & A & SD & 1 & 2 & 3 & 4 & 5 & 6 & 7 & 8 \\
\hline 1. Age & 37.17 & 10.01 & - & & & & & & & \\
2. Gender & 1.43 & 0.50 & 0.06 & - & & & & & & \\
3. Tenure & 3.56 & 1.16 & $0.68^{* *}$ & 0.08 & - & & & & & \\
4. TLI & 3.21 & 1.02 & $-0.13^{*}$ & -0.07 & $-0.18^{* *}$ & - & & & & \\
5. Autonomy & 3.45 & 0.97 & -0.10 & 0.06 & -0.08 & $0.28^{* *}$ & - & & & \\
6. Belongingness & 3.46 & 0.90 & $-0.11^{*}$ & -0.07 & $-0.16^{* *}$ & $0.38^{* *}$ & $0.48^{* *}$ & - & & \\
7. Competence & 3.79 & 0.96 & -0.05 & 0.06 & -0.03 & $0.24^{* *}$ & $0.69^{* *}$ & $0.55^{* *}$ & - & \\
8. Achievement & 3.50 & 0.92 & -0.05 & 0.01 & -0.07 & $0.34^{* *}$ & $0.64^{* *}$ & $0.50^{* *}$ & $0.72^{* *}$ & - \\
9. ACl & 4.20 & 0.54 & $0.11^{*}$ & -0.07 & 0.09 & $0.14^{* *}$ & $0.26^{* *}$ & $0.29^{* *}$ & $0.35^{* *}$ & $0.33^{* *}$ \\
\hline
\end{tabular}

Note: $* * p \leq 0.001, * * p \leq 0.01 * p \leq 0.05$

Source: Elaborated by the authors.

\section{Test of the hypotheses}

To test the hypotheses of mediation, we realized a group of regressions using the Process software of Hayes (2017). Process is an extension of SPSS and makes it possible to analyze the correlations to verify the mediational power among the independent and dependent variables.

In this study, the analysis was realized using the six variable model with four mediators (HAYES, 2017) in which transformational leadership is the independent variable, adaptive expertise is the dependent variable, and the four mediators are the need for autonomy, belongingness, competence and achievement. The regressions tested the paths as they are represented. The corrected bias effect had a confidence interval $(\mathrm{Cl})$ of $95 \%$ and the number of bias corrected samples was 5,000.

Hypothesis 1 proposes that transformational leadership is positively associated with adaptive expertise. As we can observe in Table 4, after controlling for the variables age, gender and time at work, the results of the Process analyses support Hypothesis 1 $\left(b=0.09, t_{(374)}=3.14, p \leq .05\right)$. In this manner, the transformational leader positively affects the adaptive capacity of the worker. 
Thus, the more the leader demonstrates the transformational profile, the greater the possibility is that the worker is capable of adapting to new scenarios and activities using innovation and autonomy (BREEVAART, DEMEROUTI, DERKS et al., 2016).

Transformational leadership is also positively associated with the need for autonomy $\left(b=0.27, t_{(378)}=5.63, p \leq 0.001\right)$, belongingness $\left(b=0.21, t_{(377)}=5.28, p \leq 0.001\right)$ and achievement $\left(b=0.12, t_{(376)}=3.52, p \leq 0.001\right)$. This result supports respectively Hypotheses $2 \mathrm{a}, 2 \mathrm{~b}$ and $2 \mathrm{~d}$. The transformational leader positively influences the capacity of workers to feel autonomous, belongingness, competent and realized in their activities (RATIU, DAVID and BABAN, 2017).

Hypothesis 3 proposes the interrelationship between the psychological needs of autonomy, belongingness, competence and achievement. The results confirm the positive relationship between autonomy and belongingness $\left(b=0.38, t_{(377)}=\right.$ $9.23, p \leq 0.001)$, autonomy and competence $\left(b=0.55, t_{(376)}=13.69, p \leq 0.001\right)$, autonomy and achievement $(b=0.23$, $\left.t_{(375)}=5.12, p \leq 0.001\right)$, belongingness and competence $\left(b=0.32, t_{(376)}=7.21, p \leq 0.001\right)$, belongingness and achievement $\left(b=0.07, t_{(375)}=1.70, p \leq 0.01\right)$ and between competence and achievement $\left(b=0.46, t_{(375)}=9.74, p \leq 0.001\right)$. Being personal resources, the dimensions of self-determination mutually influence each other in a significant manner, which can represent a diminution of the demands of work on the worker (ALBRECHT, 2015).

The results confirm that satisfying the psychological need for belongingness is positively associated with adaptive expertise $\left(b=0.07, t_{(374)}=2.03, p \leq 0.05\right)$; satisfying the psychological need for competence is positively associated with adaptive expertise $\left(b=0.11, t_{(374)}=2.43, p \leq 0.05\right)$ and satisfying the psychological need for achievement is positively associated with adaptive expertise $\left(b=0.09, t_{(374)}=2.01, p \leq 0.05\right)$. These results confirm Hypotheses $4 b, 4 c$ and $4 d$ respectively, and demonstrate that people with self-determination are likely to face challenges with positive behavior (GODOY and MENDONÇA, 2020; HOWARD, GAGNÉ, MORIN et al., 2016).

With these results, we have demonstrated that the relationship between transformational leadership and adaptive expertise is mediated by satisfying the needs for autonomy, belongingness, competence and empowering achievement. That is, in this study after the insertion of four mediators in the analysis, the relationship between transformational leadership and adaptive expertise ceased to be significant $\left(b=0.01, t_{(374)}=0.44, p=0,663\right)$ and the explanatory power of the model increased from $R^{2}=0.04$ to $R^{2}=0.17\left(\Delta R^{2}=0.13\right)$. The difference in the model's explanatory power when the mediators were inserted (autonomy, belongingness, competence and achievement) was an increase of $13 \%$. In this manner, in terms of Hypothesis 5 , the proposed analysis model is confirmed, given that, the explanatory power increases at the same time that the effect diminishes on the mediation model. It may be inferred from this result that the power of transformational leadership over adaptive expertise will be less significant when the worker has self-determination (CHINIARA and BENTEIN, 2016; FERNET, TRÉPANIER, AUSTIN et al., 2015; HOWARD, GAGNÉ, MORIN et al., 2016).

Table 5

Direct and Indirect Effects of Transformational Leadership and Adaptive expertise

\begin{tabular}{|c|c|c|c|c|c|c|c|c|c|c|c|c|c|c|c|}
\hline & \multicolumn{3}{|c|}{ Autonomy } & \multicolumn{3}{|c|}{ Belongingness } & \multicolumn{3}{|c|}{ Competence } & \multicolumn{3}{|c|}{ Achievement } & \multicolumn{3}{|c|}{$\mathrm{ACl}$} \\
\hline & Coef. & $\mathrm{t}$ & $\mathrm{p}$ & Coef. & $\mathrm{t}$ & $\mathrm{p}$ & Coef. & $\mathrm{t}$ & $\mathrm{p}$ & Coef. & $\mathrm{t}$ & $\mathrm{p}$ & Coef. & $\mathrm{t}$ & $\mathrm{p}$ \\
\hline Age & -0.01 & -1.17 & 0.242 & 0.00 & 0.47 & 0.637 & 0.00 & -0.12 & 0.904 & 0.00 & 0.80 & 0.424 & 0.01 & 1.75 & 0.081 \\
\hline Gender & 0.15 & 1.60 & 0.111 & -0.13 & -1.69 & 0.092 & 0.09 & 1.38 & 0.166 & -0.03 & -0.45 & 0.652 & -0.09 & -1.66 & 0.097 \\
\hline Tenure & 0.02 & 0.31 & 0.757 & -0.07 & -1.58 & 0.115 & 0.05 & 1.20 & 0.232 & 0.65 & -0.54 & 0.588 & 0.03 & 0.84 & 0.399 \\
\hline TLI (direct effect) & 0.27 & 5.63 & 0.000 & 0.21 & 5.28 & 0.000 & 0.00 & -0.35 & 0.729 & 0.12 & 3.52 & 0.000 & 0.09 & 3.14 & 0.002 \\
\hline Autonomy & & & & 0.38 & 9.23 & 0.000 & 0.55 & 13.69 & 0.000 & 0.23 & 5.12 & 0.000 & 0.00 & -0.16 & 0.876 \\
\hline Belongingness & & & & & & & 0.32 & 7.21 & 0.000 & 0.07 & 1.70 & 0.090 & 0.07 & 2.03 & 0.044 \\
\hline Competence & & & & & & & & & & 0.46 & 9.74 & 0.000 & 0.11 & 2.43 & 0.016 \\
\hline Achievement & & & & & & & & & & & & & 0.09 & 2.01 & 0.045 \\
\hline TLI (indirect effect) & & & & & & & & & & & & & 0.01 & 0.44 & 0.663 \\
\hline
\end{tabular}

Note: $* * * p \leq 0.001 * * p \leq 0.05 * p \leq 0.01$

Source: Elaborated by the authors. 


\section{CONCLUSION}

The capacity of workers to adapt to new technologies and new demands that arise from them is as important as the introduction of new technologies in achieving quality results in the public and private sector. This capacity to adapt is conditioned on a work environment which is favorable to this behavior as well as the worker's confidence in his or her capacity.

As a response to the current scenario and the changes that have occurred in the workplace, this study furthers the investigation of the explanatory power of personal resources in the SDT model, especially the impact of work resources on work demands. This study offers two important antecedents to adaptive expertise: transformational leadership and worker self-determination. In addition, it is innovative in that we present quadruple mediation with robust and detailed statistics which supports the theories and results presented here.

We have identified a positive influence of the work resource, transformational leadership, on the personal resources of workers: self-determination and adaptive expertise. In a first step of analysis, based on the Job Demand-Resources Model (JDR, BAKKER and DEMEROUTI, 2001) and the Self-Determination Theory (SDT, RYAN and DECI, 2000), the results demonstrate that transformational leaders positively influence the adaptive expertise and self-determination of workers.

Seeking to understand what influences worker behavior in the face of demands, the findings of this work reveal that self-determination have a positive impact on adaptive expertise. Self-determination conducts worker behavior, in the face of great demands, through a process of self-control and self-perception. This process alters how workers perceive their environment, face demands, and demonstrates the mediating power of the various dimensions of self-determination (satisfying the psychological needs of autonomy, belongingness, competence and achievement) in the relationship between transformational leadership and adaptive expertise.

In particular, we have verified that self-determination has been analyzed with the conceptual expansion realized by Albrecht (2015), which inserts a fourth dimension - achievement. These results make it possible, therefore, to confirm the dimensions proposed by Albrecht, and this is evident based on satisfying workers' psychological needs for autonomy, belongingness, competence and achievement.

Our findings in terms of the influence of transformational leaders and self-determination on adaptive expertise confirm our theoretical assumptions. Thus, it is understood that transformational leaders have a large impact on workers' feelings in relation to autonomy, belonging to a group, establishing good relationships and feeling valued and integrated within the work environment. Transformational leadership affects the perceptions of workers in terms of their careers and professional achievement, stimulating the search for new challenges and making full use of their knowledge and abilities. Therefore, this provides a better clarification of the role of transformational leaders in terms of self-determination and adaptive expertise.

Adaptive expertise is, therefore, a behavior considered to be a self-evolution, which may be influenced by a worker's contextual and personal factors. Based on this perspective, this study is of great scientific relevance to organizational psychology and work and furthers the evolution of studies which inform the managerial policies of people who can better respond to volatile, uncertain, complex and ambiguous scenarios in the contemporary work environment.

Finally, we have been able to demonstrate that transformational leadership and self-determination are antecedents of adaptive expertise. In this sense, the relationship between transformational leadership and adaptive expertise is mediated by satisfying needs for autonomy, belongingness, competence and achievement.

The obtained results draw attention to the importance of managerial policies and practices of people who promote organizational environments which are propitious for innovation and adaptability, the development of transformational leaders, and the promotion of worker self-determination. The variables used here - adaptive expertise, transformational leadership and self-determination - can be adopted as part of organizational analyses that inform interventions. 
The professional context and social relations appear hear as signals of the need to promote healthier environments. The management of people should be based on the personal resources of workers in their personnel management processes, directing the migration to competence behavior and its psychological needs. This directing can be part of a policy to establish personnel management processes which promote the valorization of behavioral competencies. The interference of the leader should be considered to mobilize these personal resources, becoming a variable in the processes of personnel management.

A limitation of this study is that our empirical research was realized through self-reporting, without control or the confirmation of the veracity of the information provided by the workers. In this case, we must consider the social desirability of self-determination and adaptive expertise. Another limitation to be considered relates to cultural, economic and situational issues which may interfere with the participants' evaluations. In addition, this study uses a transversal cut; there was no time control and no intervention process, and declarations made by the participating workers related to their perceptions of themselves and their leaders.

The analyses realized using this proposed model are initial. Future research should test the proposed model again, and there should also be longitudinal studies and the examination of other variables. For example: studies which relate other personal and organizational antecedents, and the insertion of other mediators in the relationship between transformational leadership and adaptive expertise. 


\section{REFERENCES}

ALBRECHT, S. L. Challenge demands, hindrance demands, and psychological need satisfaction. Journal of Personnel Psychology, v. 14, n. 2, p. 70-79, 2015.

ANTHONY, G.; HHUNTER, J.; HHUNTER, R. Prospective teachers development of adaptive expertise. Teaching and Teacher Education, v. 49, p. 108-117, July 2015.

APPEL, M.; WENDT, G. W.; ARGIMON, I. A Teoria da Autodeterminação e as influências sócio-culturais sobre a identidade. Psicologia em Revista, v. 16, n. 2, p. 351-369, 2010.

AVOLIO, B. J.; BASS, B. M.; JUNG, D. I. Reexamining the components of transformational and transactional leadership using the Multifactor Leadership. Journal of occupational and organizational psychology, v. 72, n. 4, p. 441-462, 1999.

AXELSSON, A.; JANSSON, A. A. On the Importance of Mental Time Frames: A Case for the Need of Empirical Methods to Investigate Adaptive expertise. Journal of applied research in memory and cognition, v. 7, n. 1, p. 51-59, 2018.

BAKKER, A. B.; DEMEROUTI, E. Job demands-resources theory. In: CHEN, P. Y.; COOPER, C. L. (Ed.). Work and Wellbeing: Wellbeing: A Complete Reference Guide - Volume III. Hoboken: John Wiley \& Sons, 2014. p. 1-28.

BASS, B. M. Two decades of research and development in transformational leadership. European journal of work and organizational psychology, v. 8, n. 1, p. 9-32, 1999.

BIDEE, J. et al. Daily motivation of volunteers in healthcare organizations: relating team inclusion and intrinsic motivation using self-determination theory. European Journal of Work and Organizational Psychology, v. 26, n. 3, p. 325-336, 2017.

BREEVAART, K. et al. (2016). Who takes the lead? A multi-source diary study on leadership, work engagement, and job performance. Journal of Organizational Behavior, v. 37, n. 3, p. 309-325, 2016.

BROWNE, M. W; CUDECK, R. Alternative ways of assessing model fit. In: BOLLEN, K. A.; LONG, L. S. (Orgs.). Testing structural equation models. Newbury Park: Sage, 1993. p. 1136-162.

CALAÇA, P. A.; VIZEU, F. (2015). Revisitando a perspectiva de James Mac Gregor Burns: qual é a ideia por trás do conceito de liderança transformacional? Cadernos EBAPE.BR, Rio de Janeiro, v. 13, n. 1, p. 121-135, 2015.

CARBONELL, K. et al. How experts dealwith novel situations: A review of adaptive expertise . Educational Research Review, v. 12, p. 14-29, 2014.

CARBONELL, K. et al. Measuring adaptive expertise: development and validation of an instrument. European Journal of Work and Organizational Psychology, v. 25, n. 2, p. 1-14, 2016.

CHINIARA, M.; BENTEIN, K. Linking servant leadership to individual performance: Differentiating the mediating role of autonomy, competence and relatedness need satisfaction. The Leadership Quarterly, v. 27, n. 1, p. 124-141, 2016. Available at: <http://doi. org/10.1016/j.leaqua.2015.08.004>. Accessed on: Oct. 27, 2020.

CRAWFORD, E. R.; LEPINE, J. A.; RICH, B. L. Linking job demands and resources to employee engagement and burnout: $A$ theoretical extension and meta-analytic test. Journal of Applied Psychology, v. 95, n. 5, p. 834-848, 2010. Available at: <http://doi.org/10.1037/ a0019364>. Accessed on: Oct. 27, 2020.

CRAWFORD, V. M. et al. (2005). Characterizing adaptive expertise in science teaching. In: AMERICAN EDUCATIONAL RESEARCH ASSOCIATION ANNUAL CONFERENCE, 2015, Montreal. Proceedings... Montreal: AERA, 2015

DE CORTE, E. An Innovative innovative perspective on learning and teaching in higher Education in the 21st Century. Voprosy Obrazovaniya/ Educational Studies Moscow, Moscou, n. 3, p. 8-29, 2014. Available at: <https://www.researchgate.net/publication/285030215_An_ Innovative_Perspective_on_Learning_and_Teaching_in_Higher_ Education_in_the_21st_Century>. Accessed on: Oct. 27, 2020.

DEBUSSCHER, J.; HOFMANS, J.; DE FRUYT, F. Core self-evaluations as a moderator of the relationship between task complexity, job resources, and performance. European Journal of Work and Organizational Psychology, v. 26, n. 3, p. 411-420, 2017.

DECI, E. L.; RYAN, R. M. Autonomy and need satisfaction in close relationships: Relationships motivation theory. In: Weinstein, N. (Ed.). Human motivation and interpersonal relationships. Dordrecht: Springer, 2014. p. 53-73.

EISENBERGER, R. et al. Flow experiences at work: For high need achieversal one? Journal of Organizational Behavior: The International Journal of Industrial, Occupational and Organizational Psychology and Behavior, v. 26, n. 7, p. 755-775, 2005.

FERNET, C. et al. Transformational leadership and optimal function ingat work: On the mediating role of employees' perceived job characteristics and motivation. Work \& Stress, v. 29, n. 1, p. 11-31, 2015.

GAGNÉ, M.; DECI, E. L. Self-determination theory and work motivation. Journal of Organizational behavior, v. 26, n. 4, p. $331-$ 362, 2005.

GEGENFURTNER, A. et al. Effects of ey emovement modeling examples on adaptive expertise in medical image diagnosis. Computers \& Education, v. 113, p. 212-225, 2017.

GODOY, M. T. T.; MENDONÇA, H. Inventário de Competência Adaptativa: adaptação e evidências de validade junto a trabalhadores brasileiros. Revista Psicologia: Organizações e Trabalho, v. 20, n. 1, p. 1-8, 2020.

HARDY, L. et al. The relationship between transformational leadership behaviors, psychological, and training out comes in elite military recruits. The Leadership Quarterly, v. 21, n. 1, p. 20-32, 2010.

HATANO, G.; INAGAKI, K. Two courses of expertise. Research and Clinical Center For Child Development Annual Report, v. 6, p. 27-36, 1984.

HAYES, A. F. Introduction to mediation, moderation, and conditional process analysis: A regression-based approach. Nova York: Guil Ford Publications, 2017.

HOWARD, J. et al. Motivation profiles at work: A self-determination theory approach. Journal of Vocational Behavior, v. 95, p. 74-89, 2016. 
JUDGE, T. A.; PICCOLO, R. F. Transformational and transactional leadership: a meta-analytict est of their relative validity. Journal of applied psychology, v. 89, n. 5, p. 755-768, 2004.

KLINE, P. An easy guide to fator analysis. London: Routledge, 2014.

MOSCON, D. C. B. As relações entre liderança e estabelecimento de vínculos do trabalhador nas organizações. 154f. 2015. Doctoral Dissertation (Doctor Degree in Administration) - Universidade Federal da Bahia, Salvador, 2015.

MUSTONEN, V.; HAKKARAINEN, K. Tracing two apprentices' trajectories toward adaptive professional expertise in finger print examination. Vocations and Learning, v. 8, n. 2, p. 185-211, 2015.

OLIVEIRA MACIEL, C.; NASCIMENTO, M. R. Em busca de uma abordagem não atomizada para o exame das relações entre liderança transformacional e comprometimento organizacional. Revista de Administração, v. 48, n. 3, p. 544-559, 2013.

OMAR, A.; SALESSI, S.; URTEAGA, F. Liderazgo, confianza y flexibilidad laboral como predictores de identificación organizacional: um estúdio com trabajadores argentinos. Pensamiento Psicológico, v. 14, n. 2, p. 33-47, 2016.

PODSAKOFF, N. P.; LEPINE, J. A.; LEPINE, M. A. Differential challenge stressor-hindrance stressor relationships with job attitudes, turnover intentions, turnover, and withdrawal behavior: a meta-analysis. Journal of applied psychology, v. 92, n. 2, p. 438-454, 2007.
PODSAKOFF, P. M. et al. Common method biases in behavioral research: A critical review of the literature and recommend edremedies. Journal of applied psychology, v. 88, n. 5, p. 879-903, 2003.

RATIU, L.; DAVID, O. A.; BABAN, A. Developing managerial skills through coaching: Efficacy of a cognitive-behavioral coaching program. Journal of rational-emotive $\&$ cognitive- behavior therapy, v. 34, n. 4 , p. 244-266, 2017.

REZVANI, A.; KHOSRAVI, P.; DONG, L. Motivating users toward continued usage of information systems: Self-determination theory perspective. Computers in Human Behavior, v. 76, p. 263-275, 2017.

RYAN, R. M.; DECl, E. L. Self-determination theory and the facilitation of intrinsic motivation, social development, and well-being. American psychologist, v. 55, n. 1, p. 68-78, 2000.

SCHAUFELI, W. B.; DIJKSTRA, P.; VAZQUEZ, A. C. Engajamento no trabalho. São Paulo: Casa do Psicólogo, 2013.

SOANE, E. et al. Deadly combinations: how leadership contexts undermine the activation and enactment of followers' high core self-evaluations in performance. European Journal of Work and Organizational Psychology, v. 27, n. 3, p. 297-309, 2018.

TIMS, M.; BAKKER, A. B.; XANTHOPOULOU, D. Do transformational leaders enhance their followers' daily work engagement? The Leadership Quarterly, v. 22, n. 1, p. 121-131, 2011.

TORRES, R.; SIDOROVA, A. The effect of business process configurations on user motivation. Business Process Management Journal, v. 21, n. 3, p. 541-563, 2015.

Maria Tereza Tomé de Godoy

ORCID: https://orcid.org/0000-0002-5687-1337

Ph.D. in Psychology from the Pontifical Catholic University of Goiás (PUC Goiás); Administrator at the Dean of Personnel Management at the Federal University of Goiás (UFG), Goiânia - GO, Brazil. E-mail:mttgodoy@gmail.com

Helenides Mendonça

ORCID: https://orcid.org/0000-0003-3990-5432

Ph.D. in Psychology from the University of Brasilia (UnB); Post-Doctorate from the University Institute of Lisbon (ISCTE/IUL); Full Professor at the Pontifical Catholic University of Goiás (PUC Goiás), Goiânia-GO, Brazil. E-mail: helenides@gmail.com 